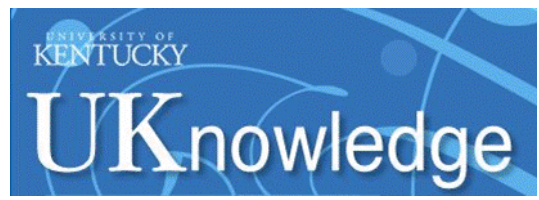

University of Kentucky

UKnowledge

Biosystems and Agricultural Engineering

Faculty Publications

Biosystems and Agricultural Engineering

1995

\title{
Regional Variation in Temperature Humidity Index for Poultry Housing
}

Richard S. Gates

University of Kentucky, gates@bae.uky.edu

Hanzhong Zhang

University of Kentucky

Donald G. Colliver

University of Kentucky, dcolliver@uky.edu

Douglas G. Overhults

University of Kentucky, doug.overhults@uky.edu

Follow this and additional works at: https://uknowledge.uky.edu/bae_facpub

Part of the Bioresource and Agricultural Engineering Commons, Environmental Sciences Commons, Geographic Information Sciences Commons, Meteorology Commons, and the Poultry or Avian Science Commons

Right click to open a feedback form in a new tab to let us know how this document benefits you.

\section{Repository Citation}

Gates, Richard S.; Zhang, Hanzhong; Colliver, Donald G.; and Overhults, Douglas G., "Regional Variation in Temperature Humidity Index for Poultry Housing" (1995). Biosystems and Agricultural Engineering Faculty Publications. 122.

https://uknowledge.uky.edu/bae_facpub/122

This Article is brought to you for free and open access by the Biosystems and Agricultural Engineering at UKnowledge. It has been accepted for inclusion in Biosystems and Agricultural Engineering Faculty Publications by an authorized administrator of UKnowledge. For more information, please contact UKnowledge@lsv.uky.edu. 
Regional Variation in Temperature Humidity Index for Poultry Housing

Digital Object Identifier (DOI)

https://doi.org/10.13031/2013.27830

Notes/Citation Information

Published in Transactions of the ASAE, v. 38, issue 1, p. 197-205.

(C) 1995 American Society of Agricultural Engineers

The copyright holder has granted the permission for posting the article here.

This article is available at UKnowledge: https://uknowledge.uky.edu/bae_facpub/122 


\title{
REgIONAL VARIATION IN TEMPERATURE HUMIDITY INDEX FOR POULTRY HOUSING
}

\author{
R. S. Gates, H. Zhang, D. G. Colliver, D. G. Overhults
}

\begin{abstract}
A building thermal model was used to compute hourly values of temperature humidity index (THI) for a broiler house with and without an evaporative misting system. Hourly summer time weather data for 238 U.S.A. locations covering 30 years were used to develop extreme occurrences of THI. Results were incorporated into a Geographical Information System (GIS) database to create isolines of THI and percentage of hours exceeding a heat stress threshold. Regional variations in misting as a suitable cooling technique are presented in terms of hours reduction in annual heat stress. The technique may be used for assisting in management decisions regarding poultry facilities housing design and siting, and with appropriate THI may be extended to other livestock production. Keywords. Heat stress, Cooling systems, Geographical Information Systems, Livestock housing.
\end{abstract}

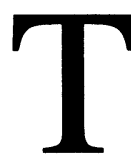
he availability of long-term hourly weather data, coupled with recent advances in Geographical Information Systems (GIS) for database manipulation and graphical presentation, has made it possible to examine regional environmental influences on livestock production. Computation of heat stress indices for a particular building configuration, environment control system and livestock species, using long-term weather data as the forcing function, can yield information on the suitability of that design. Repeating the computation with a different environmental control strategy such as evaporative cooling allows for comparison between the two control strategies as they relate to livestock heat stress (Bridges et al., 1992; Gates et al., 1991a, b).

Similar strategies have been used in the past to assess economic risk (Gates and Timmons, 1988a, b; Timmons and Gates, 1988, 1989) but a stochastic weather generation technique was employed. Axapoulos et al. (1992) evaluated heat stress intensity (HSI) for long-term Greek weather data to assess climatic impact on pork production. Significant work to develop measures of livestock physiological status and production performance as related to environment has been accomplished over the past several decades, some of which is reviewed in Gates et al. (1991a) and includes Temperature Humidity Index, Effective Temperature, Gain Reduction Factor, and Lower or Upper Critical Temperatures. There is no general agreement on which parameters are appropriate for a given species of livestock, but it is clear that these parameters should incorporate effects of moisture in the air, air

Article was submitted for publication in July 1994; reviewed and approved for publication by the Structures and Environment Div. of ASAE in October 1994.

The authors are Richard S. Gates, ASAE Member Engineer, Associate Professor, Hanzhong Zhang, Research Associate, Donald G. Colliver, ASAE Member Engineer, Associate Professor, Agricultural Engineering Dept., University of Kentucky, Lexington; and Douglas G. Overhults, ASAE Member Engineer, Associate Extension Professor, University of Kentucky, Research and Education Center, Princeton. velocity around the animal, and radiant exchange between the animal and its environment. For livestock housing it may be appropriate to neglect radiant exchange, but air velocity may be a significant factor in some housing types such as tunnel-ventilated facilities.

There are limitations to any particular measure of livestock heat stress. For example, a THI for laying hens (DeShazer and Beck, 1988) was developed from egg production data at different environments. Any environment which produces the same value of THI is presumably equivalent in terms of egg production, but not necessarily meat production or animal thermal comfort. This THI is given by:

$$
\mathrm{THI}=0.6 \mathrm{t}_{\mathrm{db}}+0.4 \mathrm{t}_{\mathrm{wb}}
$$

and has been used to assess broiler production in response to heat stress (Gates et al., 1991a, b). Within the limitations of a particular heat stress index, its application as a quantitative measure to evaluate alternate environmental control strategies is a useful tool. It is intriguing to consider extending this approach to a regional, national, or even continental basis by applying long-term summer weather data to a building thermal environment model to predict one or more heat stress indices. Some obvious applications of this approach include:

- Assessment of alternate control strategies or building configurations for a given geographical location.

- Determination of regional similarities and differences associated with a given building design.

- Determination of regional similarities and differences for a given building design with alternate environmental control strategies or equipment.

In this article we outline a method for such an analysis. A conventional, modern broiler facility was chosen as the candidate house design and the THI from equation 1 was utilized with a simple thermal environmental model. Long-term hourly summertime weather data were used to drive the model and values of THI were computed for 
outdoor conditions and for two different environmental control strategies-no misting during hot weather (NM) versus the use of moderate-pressure misting (M) for evaporative cooling.

\section{MATERIALS AND METHODS \\ Building Thermal Model}

The calculation of interior dry bulb and wet bulb temperatures was made according to the following procedure. For the nonmisting strategy interior dry bulb temperature and humidity ratio were computed from sensible and latent heat balances for the building:

$$
\begin{gathered}
t_{i, d b}=t_{o, d b}+\frac{Q_{s}\left(\text { age, } t_{o, d b}\right) n_{\text {birds }} m_{\text {birds }}}{\dot{m}_{a} c_{p}} \\
W_{i}=W_{o}+\frac{Q_{L}\left(\text { age, } t_{i, d b}\right) n_{\text {birds }} m_{\text {birds }}}{\dot{m}_{a} h_{f g}}
\end{gathered}
$$

where all variables are defined in the Appendix. Building sensible and latent heat production were evaluated from the relations for tunnel-ventilated broiler housing given by Gates et al. (1993). Sensible heat production was evaluated at outdoor conditions for simplicity to avoid an iterative solution. Relatively large birds $(1.89 \mathrm{~kg})$ were assumed and other parameters (given in table 1) were selected to represent current broiler houses. The ventilation rate represented a typical maximum ventilation rate for such buildings $(75.2 \mathrm{~kg} / \mathrm{s}$ or approximately $5.6 \mathrm{cfm} / \mathrm{bird})$. While ventilation rate in moderate weather and at night is not typically at the maximum value, this simple approach was taken to reduce the number of computations while providing extreme occurrences of THI.

For the misting strategy, interior conditions were computed from:

$$
\begin{array}{r}
t_{i, d b}=t_{o, d b}+\frac{Q_{s}\left(\text { age, } t_{o, d b}\right) n_{\text {birds }} m_{\text {birds }}-\beta \dot{\mathrm{m}}_{\mathrm{w}} \mathrm{h}_{\mathrm{fg}}}{\dot{\mathrm{m}}_{\mathrm{a}} \mathrm{c}_{\mathrm{p}}} \\
\mathrm{W}_{\mathrm{i}}=\mathrm{W}_{\mathrm{o}}+\frac{\mathrm{Q}_{\mathrm{L}}\left(\mathrm{age}, \mathrm{t}_{\mathrm{i}, \mathrm{db}} \mathrm{n}_{\text {birds }}\right) \mathrm{m}_{\text {birds }}-\beta \dot{\mathrm{m}}_{\mathrm{w}} \mathrm{h}_{\mathrm{fg}}}{\dot{\mathrm{m}}_{\mathrm{a}} \mathrm{h}_{\mathrm{fg}}}
\end{array}
$$

where the term $\beta \dot{\mathrm{m}}_{\mathrm{w}}$ represents the mass flow rate of moisture evaporated into the air (Bottcher et al., 1991).

Table 1. Parameters used for building thermal model

\begin{tabular}{ll}
\hline Number of birds & 25,000 \\
Mass of bird & $1.89 \mathrm{~kg}(4.16 \mathrm{lb})$ \\
Bird age & $40 \mathrm{~d}$ \\
Setpoint $\mathrm{t}_{\mathrm{i}, \mathrm{sp}}$ & $20^{\circ} \mathrm{C}$ \\
Misting setpoint $\mathrm{t}_{\mathrm{i}, \text { mist }}$ & $28^{\circ} \mathrm{C}$ \\
Maximum ventilation, $\dot{\mathrm{m}}_{\mathrm{a}}$ & $75.2 \mathrm{~kg} / \mathrm{s}$ (approx. $5.6 \mathrm{cfm} / \mathrm{bird})$ \\
Fraction of mist evaporated, $\beta$ & 0.33 \\
Misting flow rate, $\dot{\mathrm{m}}_{\mathrm{w}}$ & $0.1675 \mathrm{~kg} / \mathrm{s}$ (approx. $90 \mathrm{gal} / \mathrm{h})$ \\
\hline
\end{tabular}

Activation of misting occurred if:

$$
\mathrm{t}_{\mathrm{o}, \mathrm{db}}+\Delta \mathrm{t}_{\mathrm{c}} \geq \mathrm{t}_{\mathrm{i}, \mathrm{mist}}
$$

where $t_{i, \text { mist }}$ is the misting set point temperature and $\Delta t_{c}$ is an assumed increase $\left(1^{\circ} \mathrm{C}\right)$ in inside temperature with no misting used.

Wet bulb temperature was computed from psychrometric conditions (assuming standard station atmospheric pressure) from the computer routines (source code in ANSI C or Fortran 77 is available from the authors) which accompany Albright (1990).

\section{Weather Database}

Hourly weather data for the period 1961 through 1990 were used in this study. The database is called the Solar and Meteorological Surface Observation Network, or SAMSON (NCDC, 1993). The database consists of 30 years of hourly weather records for 238 U.S. locations. Dry bulb temperature, dew point temperature, and station air pressure are three of the 21 parameters included in the database. These parameters were used to compute hourly outdoor wet bulb temperature and humidity ratio. Summertime records were used (June through September) for a total of 87,840 data points per station.

\section{Data Computation and Manipulation}

The hourly weather records of dry bulb and dew point temperatures extracted from the SAMSON database were combined with computed wet bulb temperature and station pressure and stored as binary files for all 238 stations. The THI values for each hour were computed for outdoor weather conditions, and for inside conditions of both the misting and nonmisting strategies as described above. These values were also stored as binary files.

For this study, extreme occurrences were obtained from appropriate percentiles of the cumulative frequency distribution for a location. A $1 \%$ extreme occurrence corresponds to the value at the 99th percentile. Thus the $1 \%$ extreme value is exceeded by only $1 \%$ of all values. The extreme occurrences were computed by sorting THI in ascending order and counting the number of occurrences in each bin to generate a cumulative distribution. Bin widths of $0.1^{\circ} \mathrm{C} \mathrm{THI}$ were used over the range $-25^{\circ} \mathrm{C}$ to $+50^{\circ} \mathrm{C}$, for a total of 750 bins. Bins were numbered according to their magnitude in tenths of a degree with each bin having attributes of bin value and cumulative counts in the bin. For a desired percentage of extreme occurrence, the bin value containing the cumulative count representing that extrema's complement was found by a simple search. For example, if the $1 \%$ extreme occurrence is desired and there are 87,840 records of THI, then the bin containing the accumulated count of $0.99 \times 87,840=86,961$ was selected. The corresponding THI for this bin is referred to as the extreme occurrence.

Statistics for THI calculated included 1, 2.5 and 5\% extreme occurrences, mean, and standard deviations of 87,840 data points per station. Percentages of THI occurrences which exceeded thresholds of $25^{\circ}$ and $28^{\circ} \mathrm{C}$ were computed for outdoor conditions, the nonmisting strategy and the misting strategy. Interior THI depression from misting was evaluated by computing the difference in 
percentages of THI above a threshold between the nonmisting and misting control strategies.

The percentage of THI values exceeding a threshold value which represents the onset of heat stress was computed. The threshold value was first converted to a bin value (i.e., $28^{\circ} \mathrm{C}$ is bin 280 ). The ratio of the accumulated number in that bin to the total number of records (i.e., the percentile) represents the fraction of THI values at or below the heat stress threshold. Percentage of THI exceeding the threshold is thus $100 \% \times(1-$ percentile $)$. This procedure is analogous to a cooling-degree-hours analysis.

Results were presented graphically using the ARC/INFO GIS Software, (ESRI, 1992). Maps of isolines of extreme values and percentage levels were generated by importing the data and geographic coordinates of the 238 locations into an ARC/INFO database. Data coordinates were projected onto an existing U.S. map coverage (image) file. Data were analyzed and isolines computed using the triangularized irregular network (TIN) technique to generate maps of isolines.

\section{RESULTS AND DISCUSSION}

A map of mean summertime THI for outdoor conditions is given in figure 1. Mean THI is one technique for assessing regional differences under the assumptions made to compute THI. Mean outdoor THI indicates the average summertime heat stress that a broiler facility might experience assuming infinite ventilation, and provides insight into which regions experience similar summertime
THI. The means of THI can be used to indicate summer time heat distribution in the United States.

Extreme occurrences (1\%) for three cases are presented in figure 2 -outdoor conditions, inside conditions without misting (NM), and inside condition with misting (M). These values of $1 \%$ extreme occurrences for the southeastern United States exceed $29^{\circ}, 31^{\circ}$, and $30^{\circ} \mathrm{C}$, respectively, for all but the mountainous regions of Kentucky, North Carolina, South Carolina, Tennessee, and Virginia. Misting tends to result in approximately a $1^{\circ} \mathrm{C}$ reduction in extreme THI at any location. Although not shown in figure 2 , there is approximately a $2^{\circ} \mathrm{C}$ difference between values of 1 and 5\% THI for a given strategy at any location. This suggests a fairly long upper tail of the frequency distributions of THI and further indicates that THI frequency distributions are of a similar nature over much of the country.

While a $1^{\circ} \mathrm{C}$ reduction in the $1 \% \mathrm{THI}$ values predicted due to misting may at first appear minimal, it is instructive to examine the frequency distribution upper tails to further assess the impact of misting on bird heat stress. The percentages of THI values in excess of $25^{\circ} \mathrm{C}$ and $28^{\circ} \mathrm{C}$ were computed. In the southeastern United States, THI percentages in excess of $25^{\circ} \mathrm{C}$ exceed $15 \%$ for outdoor THI, and $30 \%$ for both NM and M strategies. However, when the threshold is raised to $28^{\circ} \mathrm{C}$, these values are reduced to approximately 5,10 , and $5 \%$ for the three cases, respectively (fig. 3). Thus, even with a misting system poultry can be expected to be in heat stress 5 to $25 \%$ of summertime hours in the southeastern United States.

Since the misting strategy was initiated at $27^{\circ} \mathrm{C}$ outdoor dry bulb temperature, THI values are the same for the

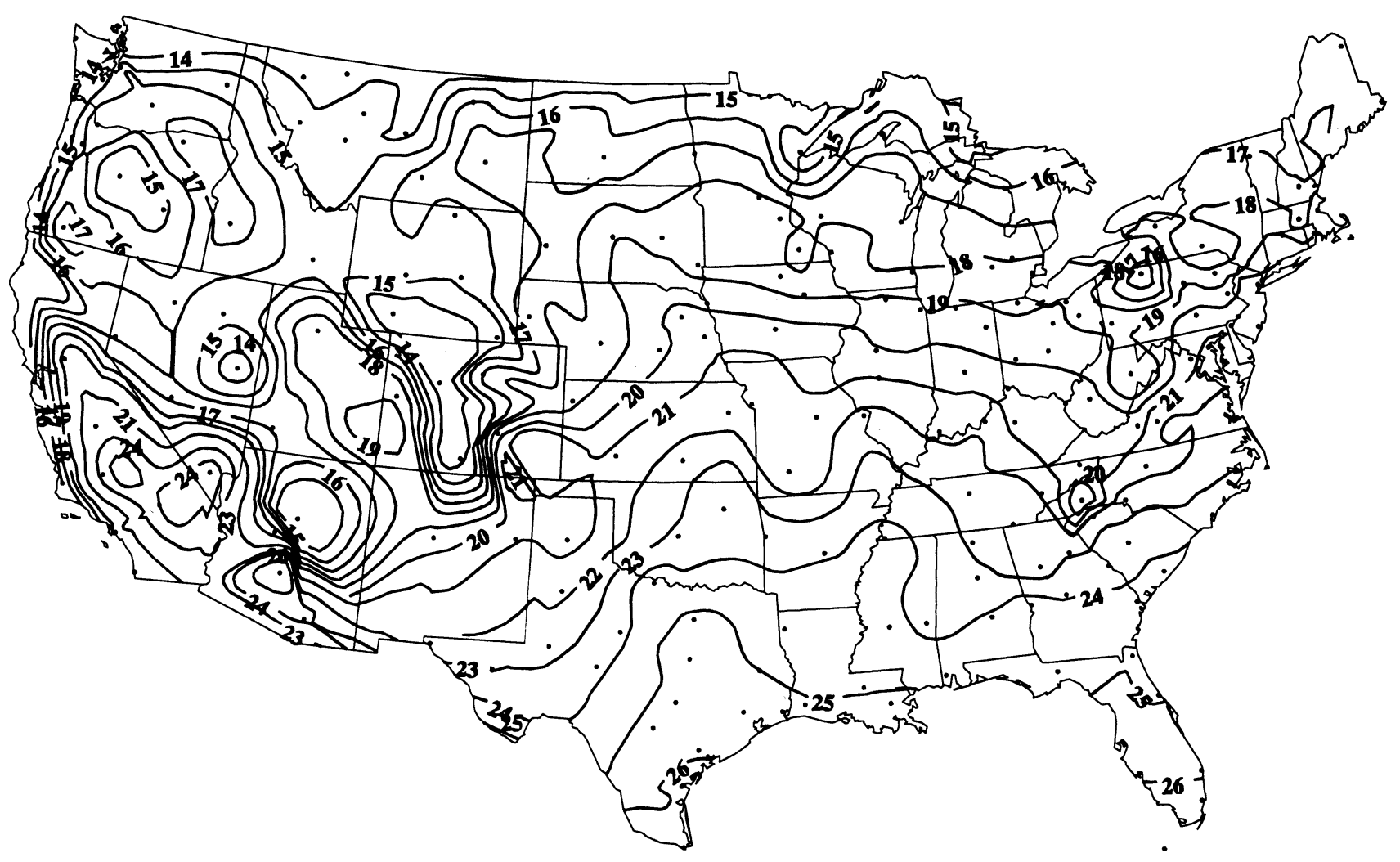

Figure 1-Mean value of temperature humidity index for outdoor summertime conditions. (THI $=0.6 t_{d b}+0.4 t_{w b}$ ) 


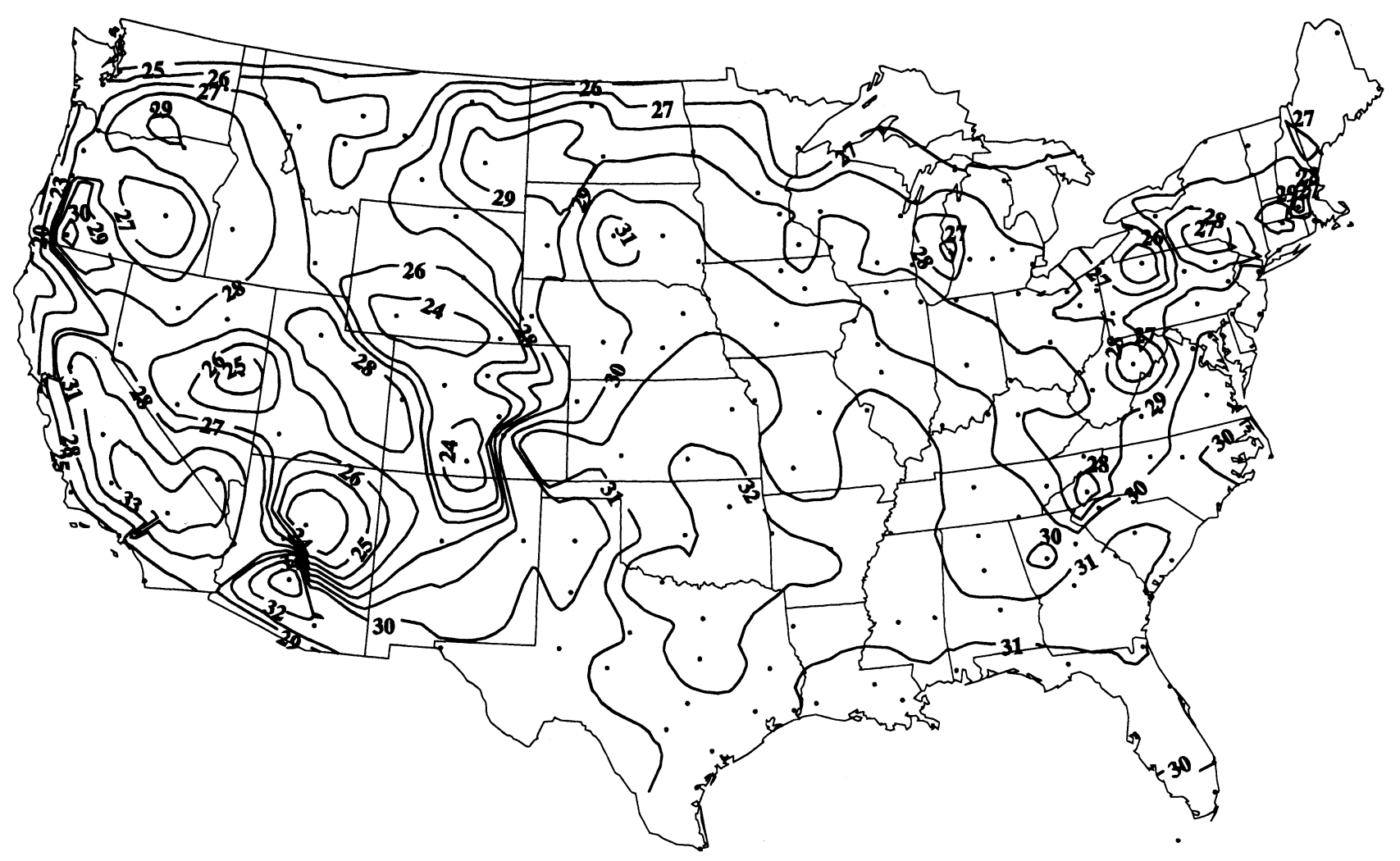

(a)

Figure 2-1\% extreme occurrences of THI. (a) Outdoor condition. (THI $=0.6 t_{d b}+0.4 t_{w b}$ )

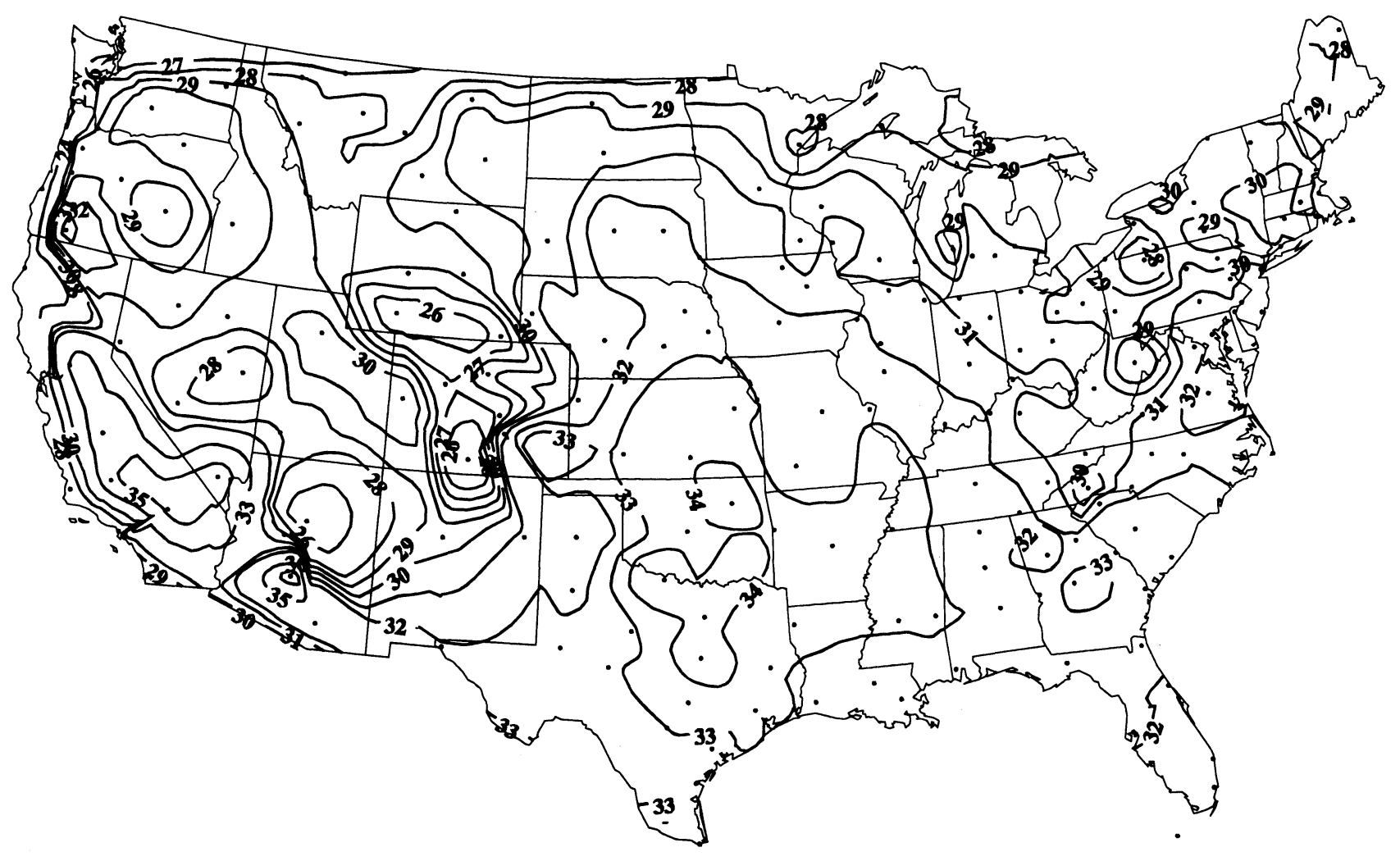

(b)

Figure 2-1\% extreme occurrences of THI. (b) Nonmisting condition. (THI $\left.=0.6 t_{d b}+0.4 t_{w b}\right)$ 


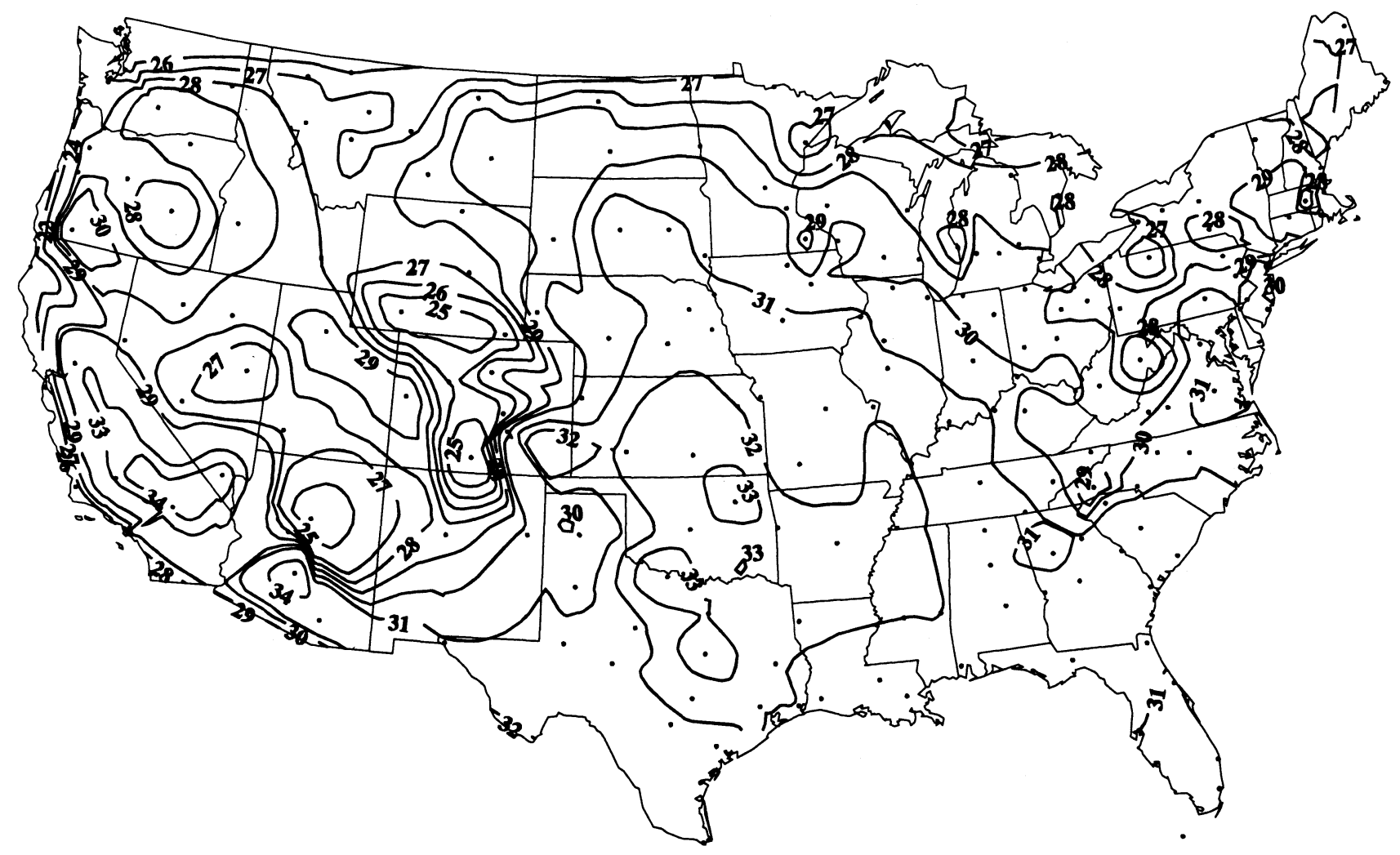

(c)

Figure 2-1\% extreme occurrences of THI. (c) Misting condition. (THI $\left.=0.6 t_{d b}+0.4 t_{w b}\right)$

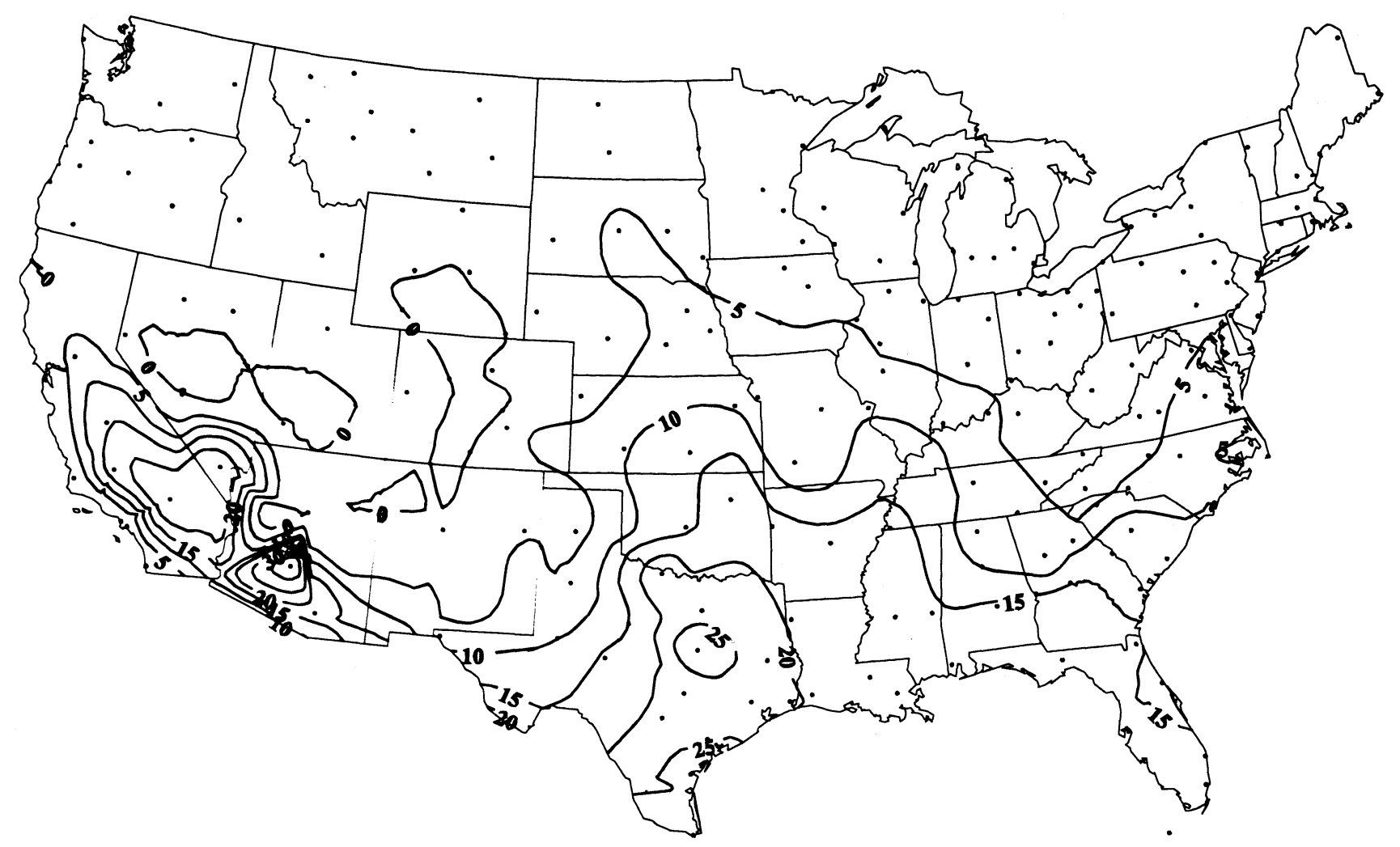

(a)

Figure 3-Percent of total summer time hours in which THI exceeded $28^{\circ} \mathrm{C}$. (a) Outdoor condition. $\left(\mathrm{THI}=0.6 \mathrm{t}_{\mathrm{db}}+0.4 \mathrm{t}_{\mathrm{wb}}\right)$ 


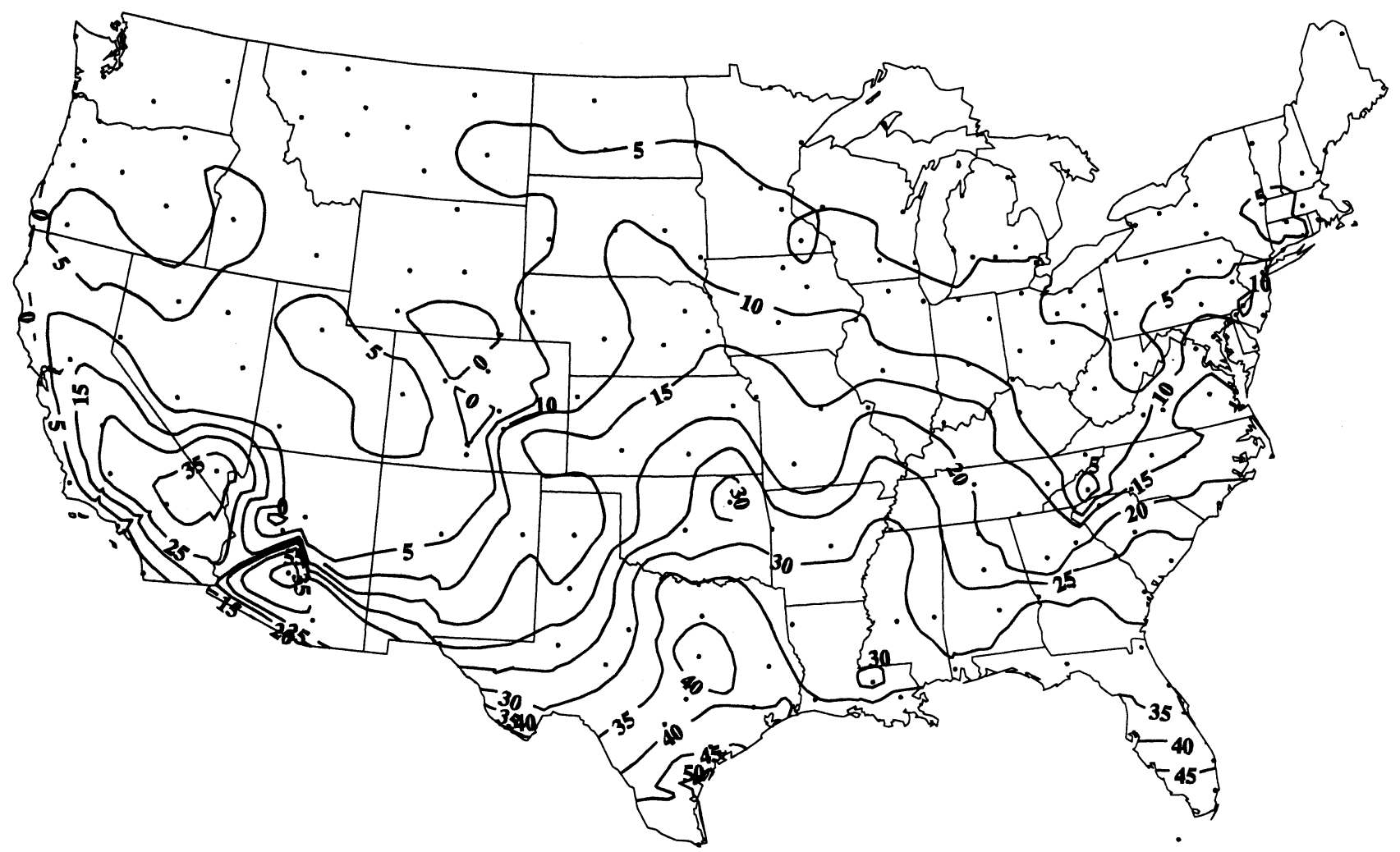

(b)

Figure 3-Percent of total summer time hours in which THI exceeded $28^{\circ}$ C. (b) Nonmisting condition. $\left(\right.$ THI $\left.=0.6 \mathbf{t}_{d b}+0.4 t_{w b}\right)$

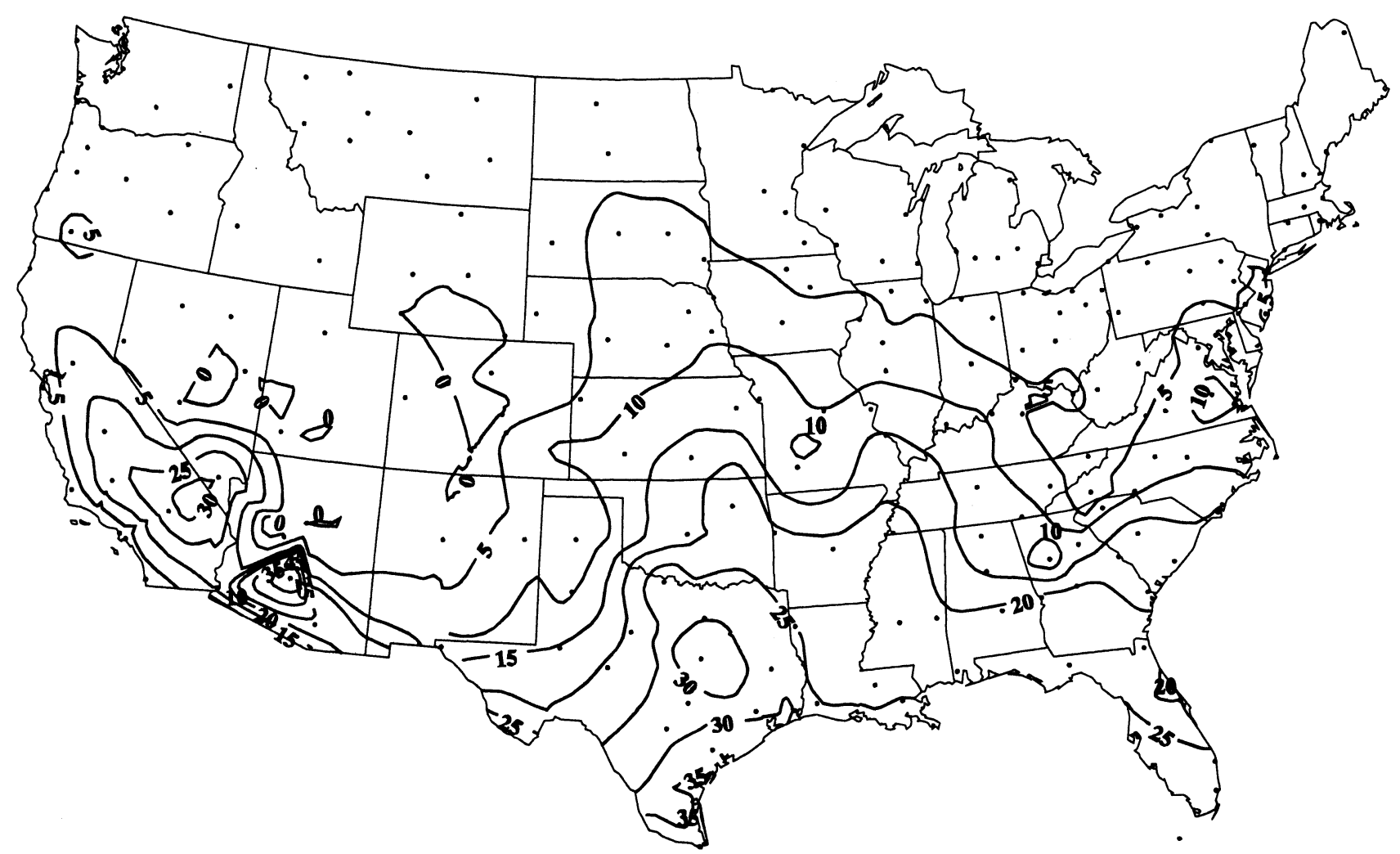

(c)

Figure 3-Percent of total summer time hours in which THI exceeded $28^{\circ} \mathrm{C}$. (c) Misting condition. $\left(\mathrm{THI}=0.6 \mathrm{t}_{\mathrm{db}}+0.4 \mathrm{t}_{\mathrm{wb}}\right)$ 


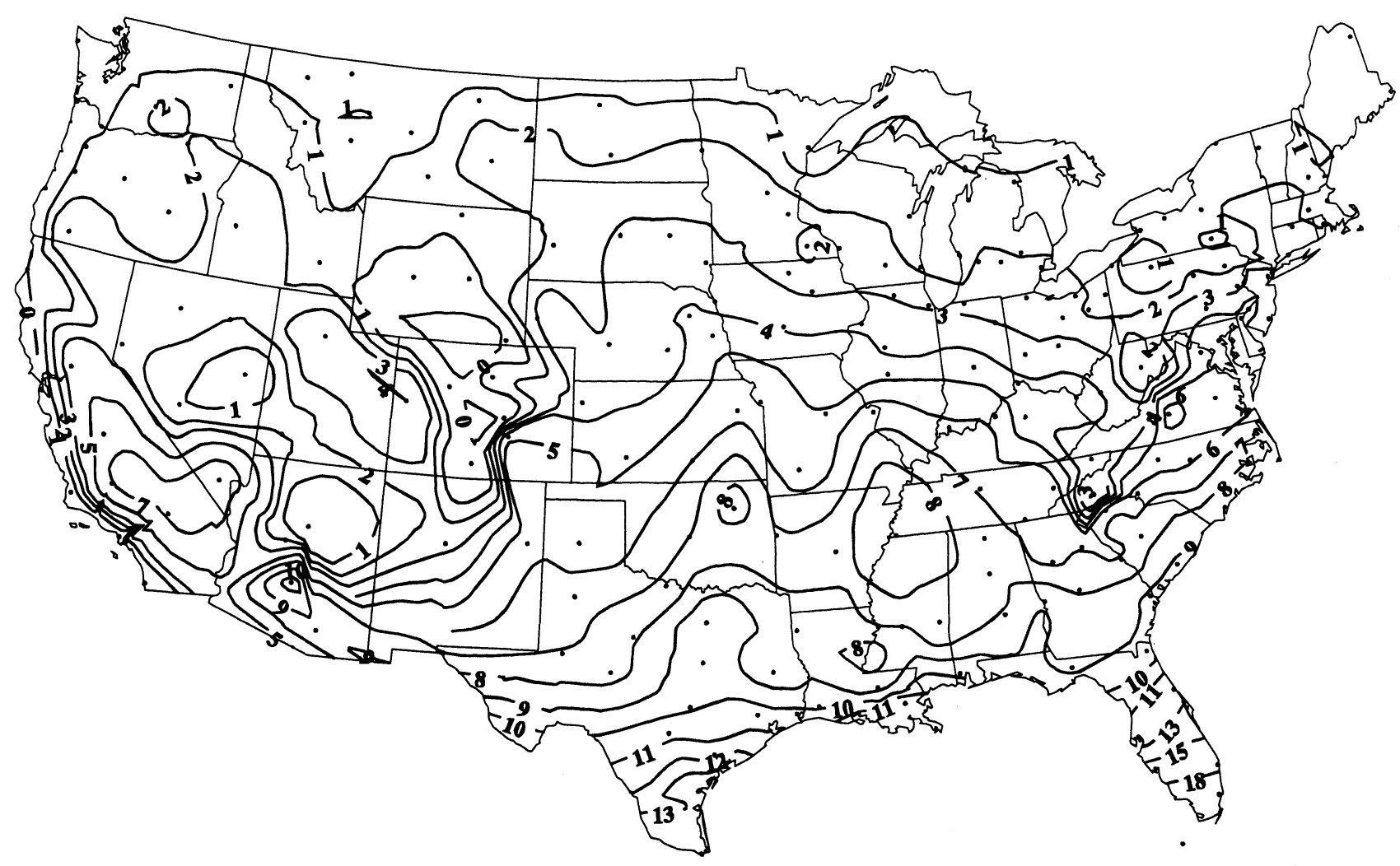

Figure 4-Differences in percent of hours in which THI exceeded $28^{\circ} \mathrm{C}$ between nonmisting and misting strategies. $\left(\right.$ THI $\left.=0.6 t_{d b}+0.4 t_{w b}\right)$

inside NM and $\mathrm{M}$ strategies for all records in which $\mathrm{t}_{\mathrm{odb}}$ is below $27^{\circ} \mathrm{C}$. This explains why the isolines of $25^{\circ} \mathrm{C}$ threshold are similar for both the NM and $\mathrm{M}$ cases. If $25^{\circ}$ $\mathrm{C}$ THI were to be used as a threshold of heat stress to birds, the effect of $M$ over NM can only be seen by using a lower misting setpoint temperature.

One difficulty with the approach as presented is that the hourly values of THI computed for the two environment control strategies are very much dependent on the assumptions made in the building thermal model and ventilation strategy. Interior conditions for mild weather and most night-time hours will be similar in both cases and the values predicted depend on specified parameters such as maximum ventilation and misting setpoint temperature. By looking at differences between these two strategies, however, the effects of the strategies are magnified by cancelling out similar conditions. Figure 4 illustrates this approach for the $28^{\circ} \mathrm{C}$ heat stress threshold by plotting isolines of percentage difference in the number of extreme occurrences in THI between NM and M strategies. For a threshold of $25^{\circ} \mathrm{C}$ (not shown in fig. 4) there is practically no difference which indicates a similar number of hours in which THI $>25^{\circ} \mathrm{C}$. However, when a threshold of $28^{\circ} \mathrm{C}$ is selected as an appropriate value for the onset of heat stress, significant differences between strategies are noted, typically $4 \%$ or greater in the southeastern United States as seen in figure 4.

The implication of these differences, in hours per summer season, is that there is significant potential for reduction in heat stress by using misting systems. The particular building configuration and bird data are from broiler houses in western Kentucky, which can realize a 7\% reduction in hours of THI $>28^{\circ} \mathrm{C}$. This same facility would experience similar benefits in northwestern Arkansas, central Tennessee, northcentral Georgia, northwestern South Carolina, and eastern North Carolina according to the isolines in figure 4 . Thus from a regional perspective, differences in summer climate between these locations are not particularly important with regards to expected heat stress. Reduction in hours of THI $>28^{\circ} \mathrm{C}$ in the southern portion of the Gulf States and north central Florida range from 9 to $12 \%$. Local microclimate may affect actual THI in any location.

Assuming the average summer spans June through September (ASHRAE, 1993) there are $2,928 \mathrm{~h}$ per summer. Thus, for an average summertime based upon the 30-year period-of-record used, a $10 \%$ reduction in hours that THI exceeds $28^{\circ} \mathrm{C}$ corresponds to $293 \mathrm{~h}$ per summer, or roughly 12 full days of potential reduction. Of course this assumes that the house is full of birds at the specified weight for an entire summer. While this may appear unrealistic it is, in fact, what occurs from the perspective of a broiler integrator in a particular region. For example, if an integrator is harvesting 1.5 million birds per week then during the summer months there are approximately 60 houses with birds at mature weights such as simulated in this analysis. Consequently, a 5\% reduction in hours of THI $>28^{\circ} \mathrm{C}$ can have a significant impact on the profitablity of an operation due to savings from reduced heat stress.

A comparison of $25^{\circ}$ versus $28^{\circ} \mathrm{C}$ as a threshold heat stress THI is given in table 2 for nine locations in the southeastern United States. These locations were selected because they are at or near experiment stations where researchers conduct work on poultry heat stress. For a 
Table 2. Percent of hours for THI exceeding a threshold*

\begin{tabular}{|c|c|c|c|c|c|c|c|c|}
\hline \multirow[b]{2}{*}{ Location } & \multicolumn{3}{|c|}{ Threshold $=25^{\circ} \mathrm{C}$} & \multicolumn{3}{|c|}{ Threshold $=28^{\circ} \mathrm{C}$} & \multicolumn{2}{|c|}{ Difference* } \\
\hline & $\begin{array}{l}\text { Out- } \\
\text { side }\end{array}$ & $\begin{array}{l}\text { Non- } \\
\text { mist- } \\
\text { ing }\end{array}$ & $\begin{array}{c}\text { Mist- } \\
\text { ing }\end{array}$ & $\begin{array}{l}\text { Out- } \\
\text { side }\end{array}$ & $\begin{array}{c}\text { Non- } \\
\text { mist- } \\
\text { ing }\end{array}$ & $\begin{array}{l}\text { Mist- } \\
\text { ing }\end{array}$ & $25^{\circ} \mathrm{C}$ & $28^{\circ} \mathrm{C}$ \\
\hline $\begin{array}{l}\text { Fayetteville, Ark. } \\
\text { Gainesville, Fla. } \\
\text { Athens, Ga. } \\
\text { Lexington, Ky. } \\
\text { Mississippi State, Miss. } \\
\text { Raleigh, N.C. } \\
\text { Clemson, S.C. } \\
\text { Knoxville, Tenn. } \\
\text { Blacksburg, Va. }\end{array}$ & $\begin{array}{l}37 \\
48 \\
28 \\
16 \\
37 \\
23 \\
23 \\
22 \\
15\end{array}$ & $\begin{array}{l}50 \\
74 \\
45 \\
29 \\
55 \\
39 \\
38 \\
37 \\
28\end{array}$ & $\begin{array}{l}49 \\
74 \\
44 \\
28 \\
54 \\
38 \\
38 \\
36 \\
26\end{array}$ & $\begin{array}{r}15 \\
18 \\
8 \\
3 \\
14 \\
6 \\
5 \\
4 \\
3\end{array}$ & $\begin{array}{l}24 \\
36 \\
19 \\
10 \\
25 \\
15 \\
15 \\
13 \\
9\end{array}$ & $\begin{array}{r}17 \\
26 \\
12 \\
5 \\
17 \\
9 \\
9 \\
7 \\
5\end{array}$ & $\begin{array}{l}1 \\
0 \\
1 \\
1 \\
1 \\
1 \\
1 \\
1 \\
1\end{array}$ & $\begin{array}{r}7 \\
10 \\
7 \\
5 \\
8 \\
6 \\
6 \\
6 \\
4\end{array}$ \\
\hline
\end{tabular}

* Some differences may not add due to rounding the percentages.

$25^{\circ} \mathrm{C}$ THI threshold, outdoor THI ranges from $15 \%$ in Blacksburg, Virginia, to $48 \%$ at Gainesville, Florida, whereas with a $28^{\circ} \mathrm{C}$ THI threshold the ranges are reduced to 3 and $18 \%$. Similar trends are noted for the interior THI predictions-Gainesville experiences $74 \%$ of all THI hours in excess of $25^{\circ} \mathrm{C}$ for either ventilation strategy, and 36 and $26 \%$ for a $28^{\circ} \mathrm{C}$ threshold for nonmisting and misting, respectively. By contrast, Blacksburg experiences 27.5 and $26.4 \% \mathrm{~h}$ in excess of $25^{\circ} \mathrm{C}$, and 8.9 and 4.9 in excess of $28^{\circ} \mathrm{C}$, for nonmisting versus misting.

Differences in percentage values of THI in excess of 25 and $28^{\circ} \mathrm{C}$ are presented for these locations in table 2 , and range from 0 at $25^{\circ} \mathrm{C}$ to $10 \%$ at $28^{\circ} \mathrm{C}$, both at Gainesville. Using $28^{\circ} \mathrm{C}$ as a reasonable threshold for onset of heat stress, these stations experience 4 to $10 \%$ reduction in heat stress hours within the building. In terms of hours per average summer (table 3), misting results in a potential for 117.4 to $292.8 \mathrm{~h}$ less heat stress per summer.

This study suggests the need for updated measurements to quantify various species' physiological response to thermal environment. The THI selected for this study was developed from 61- to 74-week-old layers, and as described earlier the coefficients were found from alternate thermal environments which resulted in similar egg production. Direct application to rapidly growing broilers with the goal of equivalent environments for meat production is only a rough approximation. Further, any new studies to quantify livestock heat stress should include air velocity as well as the moist air state point given the importance of tunnel ventilation and the lack of existing literature. Results from this study should be used with caution given the limitations of the underlying THI.

While the analysis presented was performed with broiler production parameters and tunnel-ventilated housing, it is also applicable to caged-layer facilities. Previous simulations (Timmons and Gates, 1988; Gates and Timmons, 1988a, b) on layer housing showed the economic benefits possible for evaporative pad cooling

Table 3. Annual heat stress hours in a broiler house*

\begin{tabular}{lccc}
\hline \multicolumn{1}{c}{ Location } & Nonmisting & Misting & Reduction \\
\hline Fayettevile, Ark. & 702.7 & 497.8 & 204.9 \\
Gainesville, Fla. & 1054.1 & 761.3 & 292.8 \\
Athens, Ga. & 556.0 & 354.6 & 201.4 \\
Lexington, Ky & 286.4 & 154.0 & 132.4 \\
Mississippi State, Miss. & 732.0 & 497.8 & 234.2 \\
Raleigh, N.C. & 441.5 & 267.3 & 174.2 \\
Clemson, S.C. & 429.2 & 249.8 & 179.6 \\
Knoxville, Tenn. & 394.7 & 210.5 & 184.2 \\
Blacksburg, Va. & 260.6 & 143.2 & 117.4 \\
\hline
\end{tabular}

* Assumes a THI $=28^{\circ} \mathrm{C}$ is the heat stress threshold. There are 2,928 summer hours (June through September) per year. using dry bulb temperature as the criteria which affected egg production. The THI used in this study was developed for layer production and hence use of results in table 2 and figures 1 through 4 are applicable to layer housing as well.

The THI values for NM and M strategies were computed under an assumption of a given age, bird number, bird weight, and a single setpoint temperature. A full simulation of growing birds on a regional basis may better describe thermal comfort and heat stress of broilers.

\section{CONCLUSIONS}

A building thermal model, a THI, and long-term hourly summer weather data for 238 U.S. locations were used to compute and compile extreme occurrences of THI for the continental United States. Results were presented graphically using a GIS to generate isolines of THI and differences in hours of heat stress for two treatments.

For the assumed building parameters, summertime ventilation strategies and a broiler house with 25,000 40-day-old birds, the following conclusions can be made:

- Mean occurrences of outdoor THI varied from 14 to $26^{\circ} \mathrm{C}$ in the United States.

- Values of $1 \%$ extreme occurrences of THI for outdoors, $\mathrm{NM}$, and $\mathrm{M}$ strategies were $29^{\circ}, 31^{\circ}$, and $30^{\circ} \mathrm{C}$, respectively, for most of the southeastern United States.

- Approximately $2^{\circ} \mathrm{C}$ THI difference was found between 1 and $5 \%$ extreme occurrences over most of the United States, suggesting a fairly long upper tail of each location's frequency distribution, and similar distributions among locations.

- Using a THI threshold of $28^{\circ} \mathrm{C}$ to characterize the onset of heat stress in the southeastern United States, at least 5, 10, and 5\% of summertime hours are in the heat stress category for outdoor, NM, and $M$ strategies, respectively. Maximum percentages for the region were approximately 20 , 40 , and $25 \%$, respectively.

- In terms of hours of heat stress per average summer, misting resulted in 117 to $293 \mathrm{~h}$ less heat stress for birds at nine southeastern U.S. locations.

- Maps with isolines of percentage difference between ventilation strategies provide insight into regional similarities and differences for the ventilation strategies. When developed from appropriate livestock physiological parameters, they may be useful for assessing current management practices and suggesting viable alternatives based on successful experiences at other locations with similar percentage differences.

- Geographical display of isolines of THI using a GIS provides a unique perspective to the regional effect of a ventilation strategy, and insight into regions with similar heat stress occurrences. Care should be used in interpolating between stations when local effects (lakes, mountains, etc.) could be significant.

- The method developed and described in this work requires reasonable estimates of livestock physiological response to environment. Studies to update THI (or other equivalent indices) for commercial livestock are needed to implement the method employed in this study. 
ACKNOWLEDGMENT. This work is part of CSRS Regional Project S-236 "Systems for Providing and Controlling Interior Environments for Livestock and Poultry." Acquisition of the SAMSON weather data was funded by ASHRAE grant 754-RP "Design Data for the 1, $21 / 2$, and 5\% occurrences of Extreme Dew-Point Temperature, With Mean Coincident Dry-Bulb Temperature”.

\section{REFERENCES}

Albright, L. D. 1990. Environment Control for Animals and Plants. St. Joseph, Mich.: ASAE.

ASHRAE. 1993. Handbook of Fundamentals. Atlanta, Ga.: American Society of Heating, Refrigeration and Air Conditioning Engineers.

Axapoulos, P., P. Panagakis and S. Kyritsis. 1992. Computer simulation assessment of the thermal microenvironment of growing pigs under summer conditions. Transactions of the ASAE 35(3):1005-1009.

Bottcher, R. W., G. R. Baughman, R. S. Gates and M. B. Timmons. 1991. Characterizing efficiency of misting systems for poultry. Transactions of the ASAE 34(2):586-590.

Bridges, T. C., R. S. Gates and L. W. Turner. 1992. Stochastic assessment of evaporative misting for growing-finishing swine in Kentucky. Applied Engineering in Agriculture 8(5):685-693.

DeShazer, J. A. and M. M. Beck. 1988. University of Nebraska Report for Northeast Regional Poultry Project NE-127. Lincoln: Agricultural Research Division, Univ. of Nebraska.

Environmental System Research Institute (ESRI). 1992. ARC/INFO User's Manual. Rev. 6.1. Redlands, Calif.: ESRI.

Gates, R. S., D. G. Overhults and S. H. Zhang. 1993. Heat and moisture production for modern broilers. In Proc. of Livestock Environment $I V, 761-768$, eds. E. Collins and C. Boon. 4th Int. Symp., Univ. of Warwick, Coventry, England, 6-9 July. St. Joseph: ASAE.

Gates, R. S., J. L. Usry, J. A. Nienaber, L. W. Turner and T. C. Bridges. 1991a. Optimal misting method for cooling livestock housing. Transactions of the ASAE 34(5):2199-2206.

Gates, R. S., M. B. Timmons and R. W. Bottcher. 1991b. Numerical optimization of evaporative misting systems. Transactions of the ASAE 34(10):575-580.

Gates, R. S. and M. B. Timmons. 1988a. Method to assess economic risk applied to livestock environmental control. Transactions of the ASAE 31(1):197-201.
Gates, R. S. and M. B. Timmons. 1988b. Stochastic and deterministic benefits of evaporative cooling for laying hens. Transactions of the ASAE 31(3):904-909.

NCDC. 1993. Solar and Meteorological Surface Observation Network 1961-1990. Version 1.0 (SAMSON). U.S. Department of Commerce, National Climatic Data Center, Asheville, N.C.; and U.S. Department of Energy, National Renewable Energy Laboratory, Golden, Colo.

Timmons, M. B. and R. S. Gates. 1989. Temperature dependent efficiency of evaporative cooling for broilers. Applied Engineering in Agriculture 5(2):215-224.

Timmons, M. B. and R. S. Gates. 1988. Predictive model of evaporative cooling and laying hen performance to air temperature and evaporative cooling. Transactions of the ASAE 31(5):1503-1509.

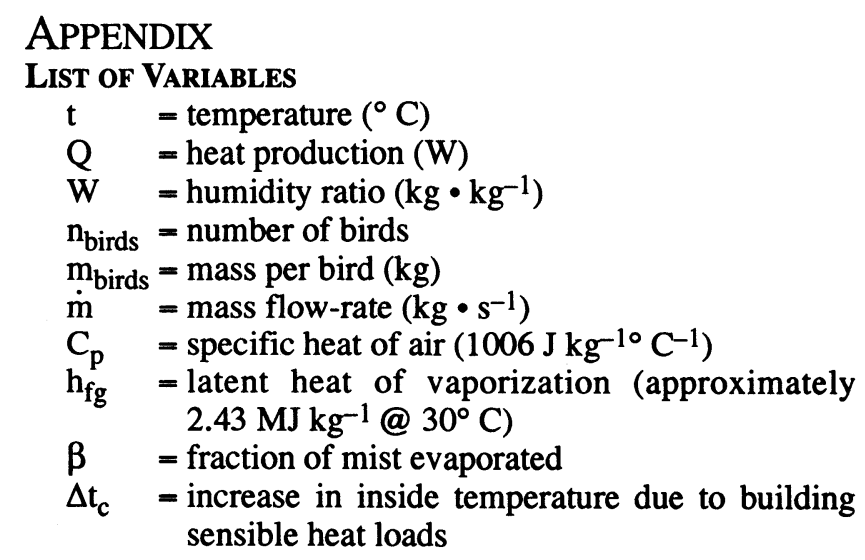

$\begin{aligned} & \text { SUBSCRIPTS } \\ & \mathrm{i}=\text { inside } \\ & \mathrm{o}=\text { outdoor } \\ & \mathrm{db}=\text { dry bulb temperature } \\ & \mathrm{wb}=\text { wet bulb temperature } \\ & \mathrm{S}=\text { sensible heat } \\ & \mathrm{L}=\text { latent heat } \\ & \mathrm{a}=\text { air flow } \\ & \mathrm{w}=\text { water flow }\end{aligned}$

